\title{
Levels of lysine and methionine+cystine for growing New Zealand White rabbits
}

\author{
Ana Carolina Monteiro-Motta ${ }^{1}$, Cláudio Scapinello ${ }^{1}$, Andréia Fróes Galuci Oliveira ${ }^{1}$, Josianny \\ Limeira Figueira ${ }^{1}$, Fernanda Catelan ${ }^{1}$, Joyce Sato ${ }^{1}$, Caroline Espejo Stanquevis ${ }^{1}$
}

${ }^{1}$ Departamento de Zootecnia, Universidade Estadual de Maringá, Maringá, PR, Brasil.

\begin{abstract}
Two experiments were carried out to evaluate, respectively, nitrogen balance (NB) and the productive performance of 31-to-50-day-old rabbits subjected to different levels of lysine and methionine + cystine (met + cys). Seventy-five animals were randomly distributed in $5 \times 3$ blocks (five levels of lysine: $5.5,6.5,7.5,8.5$ and $9.5 \mathrm{~g} / \mathrm{kg}$ combined with three levels of met+cys: $5.0,6.0$ and $7.0 \mathrm{~g} / \mathrm{kg}$ ), with 15 treatments and five replications for the NB assay. The assay lasted 14 days: 10 days for acclimatization and four days for feces and urine collection. Increasing met + cys levels had a quadratic effect on the nitrogen excreted in urine (NU): the lowest excretion was found at the dietary level of $5.9 \mathrm{~g} / \mathrm{kg}$ met + cys. Increasing lysine levels also affected NU and nitrogen retained daily (NR): the lowest NU was obtained at the dietary level of $7.28 \mathrm{~g} / \mathrm{kg}$ lysine, and maximum NR was found at $7.24 \mathrm{~g} / \mathrm{kg}$ lysine. Increases in met+cys levels in the diets affected neither performance nor carcass characteristics of rabbits up to 50 days of age. On the other hand, body weight at 50 days, daily weight gain and feed conversion of rabbits slaughtered at 50 days had a quadratic effect as the lysine levels increased. The best results were found at 7.5, 7.38 and $7.36 \mathrm{~g} / \mathrm{kg}$ lysine. Lysine and met+cys levels of 7.4 and $5.0 \mathrm{~g} / \mathrm{kg}$ in the diet are recommended for 31-to-50-day-old rabbits.
\end{abstract}

Key Words: amino acids, carcass, nitrogen balance, performance

\section{Introduction}

In order to synthesize body protein and other products, rabbits require all amino acids simultaneously. However, some of these amino acids are not synthesized at all, or are synthesized in insufficient amounts by the body; these are known as essential amino acids, requiring supplementation from the diet (De Blas \& Wiseman, 1998). As such, the required dietary protein level for rabbits varies according to certain aspects such as the amino acid profile, the degree to which protein is digested, the amount of feed ingested and the physiological stage of the animal.

Rabbit diets are formulated basically with plantbased items, featuring soybean meal as the main source of protein. The addition of roughage, including grasses and legumes, represents approximately $350 \mathrm{~g} / \mathrm{kg}$ to $400 \mathrm{~g} / \mathrm{kg}$ of feed composition. Because of the nutritional features of these ingredients, there is need for supplementation of more limiting amino acids. Scapinello et al. (1995a) have cited methionine, and at times lysine and threonine for growing and breeding rabbits.

Of all amino acids, lysine is the only one to play a metabolic role almost exclusively to add body protein - that is, for meat deposition (Champe \& Harvey, 1997), since amino acids are generally related to protein synthesis.
Under normal conditions, methionine can be catabolized and converted into cystine; however, this process is not reversible, as cystine cannot be converted into methionine. Therefore, it is necessary to determine the levels of these amino acids in order to meet this interrelation (Barbosa et al., 2002).

Studies to determine the required levels of amino acids for rabbits began in the 1960s (McWard et al., 1967; Gaman \& Fisher, 1970; Cheeke, 1971; Adamson \& Fisher, 1971, 1973), with those focusing on commercial animals starting in the 1970s (Lebas et al., 1973; Colin, 1975; Davison \& Spreadbury 1975; Spreadbury, 1978) and forming the basis of the nutritional recommendations included in the NRC (NRC, 1977).

The nutritional requirements of lysine and methionine+cystine for growing rabbits indicated in the literature vary considerably. For lysine, values range between $5.0 \mathrm{~g} / \mathrm{kg}$ and $8.5 \mathrm{~g} / \mathrm{kg}$ of inclusion in the diet (Gomes et al., 1992; Scapinello et al., 1995a; Carregal, 1998; De Blas \& Wiseman, 1998; Lebas, 2004). For amino acids methionine + cystine, recommendations vary from $4.64 \mathrm{~g} / \mathrm{kg}$ to $6.1 \mathrm{~g} / \mathrm{kg}$ of inclusion in diet (NRC, 1977; Pinto \& Carregal, 1994; Scapinello et al., 1995b; De Blas \& Wiseman, 1998; Gomes et al., 2005; Ojewola et al., 2006), which hinders nutritionists in devising a nutritional plan for each animal stage. 
The majority of studies on amino acid requirements for rabbits have been carried out considering the entire production period, from weaning (31-35 days) to slaughter (60-70 days), without considering that animals have different requirements and growth rates according to their physiological stage and phenotypic aspects.

The objective of this work was to study the effect of different levels of lysine and methionine+cystine in the diets of New Zealand White (NZW) rabbits during the growth stage between 31 and 50 days of age, by means of a nitrogen balance test and a performance-cost ratio trial.

\section{Material and Methods}

The nitrogen balance and growth experiments between 31 and 50 days of age were carried out at the Cuniculture Sector of the Iguatemi Experimental Farm (FEI), belonging to Universidade Estadual de Maringá (UEM), located in the state of Paraná $\left(23^{\circ} 25^{\prime} \mathrm{S}, 51^{\circ} 57^{\prime} \mathrm{W}\right.$, at an elevation of 550 meters), between August and September 2008. The low and high average temperatures recorded during the experimental period were $16.5 \pm 2.8$ and $24.9 \pm 3.4^{\circ} \mathrm{C}$, respectively.

For the nitrogen balance experiment, seventy-five 31-day-old New Zealand White rabbits were housed individually in metabolism cages measuring $30 \times 50 \mathrm{~cm}$ (width and depth), provided with automatic drinkers, semiautomatic feeders and devices to collect feces and urine separately.

The animals were arranged in a completely randomized design, with 15 treatments and five replications, with treatments arranged in a $5 \times 3$ factorial design (lysine levels: $5.5,6.5,7.5,8.5$ and $9.5 \mathrm{~g} / \mathrm{kg}$, and methionine+cystine levels: $5.0,6.0$ and $7.0 \mathrm{~g} / \mathrm{kg}$ ).

All animals were weaned at the same age ( 31 days) and later received the diets (Table 1), formulated according to the recommendations of De Blas \& Wiseman (1998) so that all had the same energy and nutritional values, with addition of increasing levels of lysine and methionine+cystine,

Table 1 - Chemical composition of experimental diets for early-stage rabbits ( 31 to 50 days)

\begin{tabular}{|c|c|c|c|c|c|c|c|c|c|c|c|c|c|c|c|}
\hline \multirow{2}{*}{$\begin{array}{l}\text { Met }+ \text { cys levels }(\mathrm{g} / \mathrm{kg}) \\
\text { Lysine levels }(\mathrm{g} / \mathrm{kg})\end{array}$} & \multicolumn{5}{|c|}{5.0} & \multicolumn{5}{|c|}{6.0} & \multicolumn{5}{|c|}{7.0} \\
\hline & 5.5 & 6.5 & 7.5 & 8.5 & 9.5 & 5.5 & 6.5 & 7.5 & 8.5 & 9.5 & 5.5 & 6.5 & 7.5 & 8.5 & 9.5 \\
\hline \multicolumn{16}{|l|}{ Ingredients (g/kg) } \\
\hline Coast cross hay & 233.0 & 233.0 & 233.0 & 233.0 & 233.0 & 233.0 & 233.0 & 233.0 & 233.0 & 233.0 & 233.0 & 233.0 & 233.0 & 233.0 & 233.0 \\
\hline Wheat bran & 200.0 & 200.0 & 200.0 & 200.0 & 200.0 & 200.0 & 200.0 & 200.0 & 200.0 & 200.0 & 200.0 & 200.0 & 200.0 & 200.0 & 200.0 \\
\hline Pelletized alfalfa & 195.7 & 195.7 & 195.7 & 195.7 & 195.7 & 195.7 & 195.7 & 195.7 & 195.7 & 195.7 & 195.7 & 195.7 & 195.7 & 195.7 & 195.7 \\
\hline Soybean meal $450 \mathrm{~g} / \mathrm{kg}$ & 51.0 & 51.0 & 51.0 & 51.0 & 51.0 & 51.0 & 51.0 & 51.0 & 51.0 & 51.0 & 51.0 & 51.0 & 51.0 & 51.0 & 51.0 \\
\hline Lime $380 \mathrm{~g} / \mathrm{kg}$ & 7.4 & 7.4 & 7.4 & 7.4 & 7.4 & 7.4 & 7.4 & 7.4 & 7.4 & 7.4 & 7.4 & 7.4 & 7.4 & 7.4 & 7.4 \\
\hline Inert (sand) & 7.3 & 6.0 & 4.7 & 3.5 & 2.2 & 6.3 & 5.0 & 3.7 & 2.5 & 1.2 & 5.3 & 4.0 & 2.7 & 1.4 & 0.2 \\
\hline Common salt & 4.0 & 4.0 & 4.0 & 4.0 & 4.0 & 4.0 & 4.0 & 4.0 & 4.0 & 4.0 & 4.0 & 4.0 & 4.0 & 4.0 & 4.0 \\
\hline Dicalcium phosphate $180 \mathrm{~g} / \mathrm{kg}$ & $\lg 3.0$ & 3.0 & 3.0 & 3.0 & 3.0 & 3.0 & 3.0 & 3.0 & 3.0 & 3.0 & 3.0 & 3.0 & 3.0 & 3.0 & 3.0 \\
\hline Min - rabbit ${ }^{1}$ & 2.5 & 2.5 & 2.5 & 2.5 & 2.5 & 2.5 & 2.5 & 2.5 & 2.5 & 2.5 & 2.5 & 2.5 & 2.5 & 2.5 & 2.5 \\
\hline Vit - rabbit $^{1}$ & 2.5 & 2.5 & 2.5 & 2.5 & 2.5 & 2.5 & 2.5 & 2.5 & 2.5 & 2.5 & 2.5 & 2.5 & 2.5 & 2.5 & 2.5 \\
\hline Protein $(g / k g)^{3}$ & 170.0 & 170.0 & 170.0 & 170.0 & 170.0 & 170.0 & 170.0 & 170.0 & 170.0 & 170.0 & 170.0 & 170.0 & 170.0 & 170.0 & 170.0 \\
\hline $\operatorname{NDF}(g / k g)^{4}$ & 344.1 & 392.4 & 433.8 & 389.4 & 382.7 & 369.6 & 382.7 & 347.8 & 382.9 & 372.2 & 373.9 & 387.1 & 364.0 & 383.5 & 388.0 \\
\hline $\operatorname{ADF}(g / k g)^{4}$ & 175.3 & 191.5 & 200.1 & 196.8 & 190.1 & 177.0 & 188.9 & 175.5 & 196.8 & 195.9 & 177.2 & 193.6 & 183.0 & 194.1 & 194.0 \\
\hline $\mathrm{DE}(\mathrm{kcal} / \mathrm{kg})^{3}$ & 2600 & 2600 & 2600 & 2600 & 2600 & 2600 & 2600 & 2600 & 2600 & 2600 & 2600 & 2600 & 2600 & 2600 & 2600 \\
\hline Total lysine $(\mathrm{g} / \mathrm{kg})^{3}$ & 5.5 & 6.5 & 7.5 & 8.5 & 9.5 & 5.5 & 6.5 & 7.5 & 8.5 & 9.5 & 5.5 & 6.5 & 7.5 & 8.5 & 9.5 \\
\hline Total met + cys $(\mathrm{g} / \mathrm{kg})^{3}$ & 5.0 & 5.0 & 5.0 & 5.0 & 5.0 & 6.0 & 6.0 & 6.0 & 6.0 & 6.0 & 7.0 & 7.0 & 7.0 & 7.0 & 7.0 \\
\hline Total phosphorus $(\mathrm{g} / \mathrm{kg})^{4}$ & 5.0 & 5.0 & 5.0 & 5.0 & 5.0 & 5.0 & 5.0 & 5.0 & 5.0 & 5.0 & 5.0 & 5.0 & 5.0 & 5.0 & 5.0 \\
\hline Calcium $(\mathrm{g} / \mathrm{kg})^{4}$ & 10.0 & 10.0 & 10.0 & 10.0 & 10.0 & 10.0 & 10.0 & 10.0 & 10.0 & 10.0 & 10.0 & 10.0 & 10.0 & 10.0 & 10.0 \\
\hline Cost $/ \mathrm{kg}(\mathrm{R} \$)^{5}$ & 0.57 & 0.58 & 0.59 & 0.59 & 0.60 & 0.58 & 0.59 & 0.60 & 0.61 & 0.62 & 0.60 & 0.61 & 0.61 & 0.63 & 0.64 \\
\hline
\end{tabular}

NDF - neutral detergent fiber; ADF - acid detergent fiber; DE - digestible energy.

${ }^{1}$ Nuvital, composition per kg of product: vit. A - 600,000 IU; vit. D - 100,000 IU; vit. E - 8,000 mg; vit. K3 - 200 mg; vit. B1 - 400 mg; vit. B2 - 600 mg; vit. B6 - 200 mg; vit. B12 - 2,000 mcg; pantothenic acid - 2,000 mg; choline - 70,000 mg; Fe - 8,000 mg; Cu - 1,200 mg; Co - $200 \mathrm{mg}$; Mn - 8,600 mg; Zn - $12,000 \mathrm{mg}$; I - $64 \mathrm{mg}$; Se - $16 \mathrm{mg}$; antioxidant $-20,000 \mathrm{mg}$.

${ }_{2}$ Active ingredient based on robenidine $(66 \mathrm{~g} / \mathrm{kg})$

${ }^{3}$ Calculated according to De Blas \& Wiseman (1998).

${ }^{4}$ Analyzed values.

${ }^{5}$ Price per kg of product in Brazilian Reais $(\mathrm{R} \$)$. 
according to treatment. Diets were supplemented with synthetic amino acids in sufficient amounts to achieve the desired ratios between the amino acids. To balance the diets, the levels of amino acids under study were considered in all ingredients used, according to calculated values.

The rations were dry-pelletized and provided ad libitum, as was water.

The experiment lasted 14 days - 10 days for acclimatization to the cages and diets, and four days for collection of feces and urine, following the European reference method for in vivo determination of diet digestibility (EGRAN, 1999). The feces of each animal were collected in their entirety once a day, in the morning, placed in plastic bags and stored in a freezer at $-10^{\circ} \mathrm{C}$.

Later, the feces of each animal were placed in a forced air oven at $55{ }^{\circ} \mathrm{C}$ for 72 hours for pre-drying. After predrying, the feces were milled and sent to the laboratory for nitrogen level quantification. The nitrogen level of the experimental diets and feces was obtained using the Kjeldahl method, according to Silva \& Queiroz (2002).

The urine of each animal was collected in a glass recipient, containing $10 \mathrm{~mL}$ of a $1: 1 \mathrm{HCl}: \mathrm{H}_{2} \mathrm{O}$ solution, to avoid bacterial proliferation and possible losses by volatilization. The chemical composition of feces, urine and feed was determined at the Food Analysis and Animal Nutrition Laboratory (LANA) of Universidade Estadual de Maringá (UEM), according to the methodologies described by Silva \& Queiroz (2002).

The values of nitrogen consumption (NC), nitrogen excreted in feces (NF) and nitrogen excreted in urine (NU) were obtained by multiplying nitrogen levels by the amounts of feed ingested and of feces and urine excreted, respectively; from those values, retained nitrogen was calculated as $\mathrm{RN}=\mathrm{NC}-\mathrm{NF}-\mathrm{NU}$.

For the performance assay, 180 New Zealand White animals between 31 and 50 days of age were used in a completely randomized factorial design with 15 treatments (Table 1), already described in the previous test, and 12 replications, with one animal per experimental unit.

The animals were weighed at the start (31 days of age) and end (50 days of age) of the experiment, when they were slaughtered to evaluate weight gain, feed intake, average diet cost, feed conversion, carcass weight and yield, weight and yield of commercial meat cuts, and meat:bone ratio.

To calculate the costs of experimental diets, the following prices of ingredients in the region of Maringá/PR, Brazil in November 2010 were used: coast cross hay, R $\$ 0.37 / \mathrm{kg}$; corn, $\mathrm{R} \$ 0.40 / \mathrm{kg}$; wheat bran, $\mathrm{R} \$ 0.43 / \mathrm{kg}$; alfalfa, $\mathrm{R} \$ 0.80 / \mathrm{kg}$; soybean meal, R\$ $0.78 / \mathrm{kg}$; gluten $600 \mathrm{~g} / \mathrm{kg}, \mathrm{R} \$ 0.76 / \mathrm{kg}$; soybean oil, R\$ 2.16/kg; limestone, R\$ 0.20/kg; common salt, $\mathrm{R} \$ 0.51 / \mathrm{kg}$; dicalcium phosphate, $\mathrm{R} \$ 1.67 / \mathrm{kg}$; mineral supplement, R\$ 4.25/kg; vitamin supplement, R\$ 4.25/kg; DL-methionine, R\$ $11.80 / \mathrm{kg}$; L-lysine $\mathrm{HCl}, \mathrm{R} \$ 5.80 / \mathrm{kg}$; and coccidiostat, $\mathrm{R} \$ 10.75 / \mathrm{kg}$. The estimated costs of commercial diets were restricted to the costs of the raw materials used.

In order to assess the economic cost of the treatments, the average cost of diet was determined per kilogram of body weight during the experimental period ( $\mathrm{Y} i$ ), according to Bellaver et al. (1985):

$$
\mathrm{Y} i=\frac{\mathrm{Q} i x \mathrm{P} i}{\mathrm{G} i},
$$

in which: $\mathrm{Y} i=$ mean cost in diet per kilogram gained in the $i$-th treatment; $\mathrm{Q} i=$ mean amount of feed consumed in the $i$-th treatment; $\mathrm{P} i=$ mean price per kilogram of the diet used in the $i$-th treatment; $\mathrm{G} i=$ mean weight gain of the $i$-th treatment.

Carcass weights and yields were obtained using the hot carcass with the head and without edible viscera (heart, liver and kidneys), which were weighed separately.

To obtain the meat:bone ratio, the hind right leg was weighed and deboned, according to the methodology described by Rao et al. (1978):

$$
\mathrm{MBR}=\underline{\mathrm{MW}},
$$

in which: $\mathrm{MBR}=$ meat:bone ratio; $\mathrm{MW}=$ meat weight $(\mathrm{g})$; $\mathrm{BW}=$ bone weight $(\mathrm{g})$.

The statistical analysis was performed by regression analysis, according to the following statistical model:

$$
\mathrm{Y}_{i j k}=\mu+\mathrm{L}_{i}+\mathrm{M}_{j}+\mathrm{LM}_{i j}+\beta \mathrm{X}_{i j k}+\mathrm{e}_{i j k}
$$

in which: $\mathrm{Y}_{i j k}$ is the measurement taken in the $k$-th animal receiving the $i \times j$-th combination of levels of lysine and methionine + cystine. The term $\mu$ represents the overall mean; $\mathrm{L}_{i}$ is the $i$-th lysine level (i.e., 5.5, 6.5, 7.5, 8.5 and $9.5 \mathrm{~g} / \mathrm{kg}$ of diet); $\mathrm{M}_{j}$ is the $j$-th methionine+cystine level of inclusion in the diet (i.e., $5.0,6.0$ and $7.0 \mathrm{~g} / \mathrm{kg}$ ); $\mathrm{LM}_{i j}$ is the interaction effect; $\beta$ is coefficient of regression of the observed variables against the initial body weight of the $k$-th animal at 31 days of age as the covariate $\mathrm{X}_{i j k}$; and $\mathrm{e}_{i j k}$ is the random error term under the assumptions of normality, independence and homoscedasticity, i.e., $\mathrm{e}_{i j k} \sim N\left(0, \sigma^{2}\right)$. The model was fitted by using SAEG (Sistema de Análises Estatísticas e Genéticas, version 5.0).

\section{Results and Discussion}

There was no interaction $(\mathrm{P}>0.05)$ between levels of lysine and methionine + cystine for any of the characteristics 
linked to the study of nitrogen balance in rabbits between 31 and 50 days of age (Table 2). This indicates that the levels of lysine and methionine+cystine acted independently.

Quadratic effects $(\mathrm{P}<0.05)$ were observed of the growing levels of lysine on the daily amount of nitrogen excreted in urine (NU) and on nitrogen retained daily, estimating that the diet containing $7.28 \mathrm{~g} / \mathrm{kg}$ of lysine had the lowest NU and the highest nitrogen retention occurred when the diet had $7.24 \mathrm{~g} / \mathrm{kg}$ of lysine.

The obtained results are close to those found by Gomes et al. (1992), who observed improved performance when lysine supplementation increased from 5.5 to $8.5 \mathrm{~g} / \mathrm{kg}$; however, those authors worked with subprime protein levels $(133 \mathrm{~g} / \mathrm{kg} \mathrm{CP})$ in the diets.

In the present study, quadratic effect $(\mathrm{P}<0.05)$ of the growing levels of methionine+cystine was observed on NU, with the lowest excretion when the diet showed $5.9 \mathrm{~g} / \mathrm{kg}$ inclusion of that amino acid in the diet, indicating improved yield of the amino acid and consequently lower excretion in urine.

The quadratic effect observed for the levels of lysine and methionine+cystine is likely associated with the supply of amino acids at levels closer to animal needs, thus allowing increased protein use efficiency and maximized use of amino acids for protein synthesis, minimizing their use as an energy source (Pinto \& Carregal, 1994).
The results found in this trial $(5.9 \mathrm{~g} / \mathrm{kg})$ are close to those found by Scapinello et al. (1995b), who estimated a $6.0 \mathrm{~g} / \mathrm{kg}$ requirement of methionine+cystine in the diet; however, that is a representative average in which animals were evaluated in two periods (35-70 and 35-90 days of age).

Sakomura \& Rostagno (2007) describe that the doseresponse method is based on the animal response to increased intake of a given nutrient. According to Rutz (2002), when an organism cannot obtain sufficient amounts of an essential amino acid from the diet, it catabolizes body protein to obtain that amino acid.

As the supply of amino acids is adjusted according to animal requirements, their excretion is minimized, allowing for better nitrogen use and consequently improving the productive performance and minimizing nitrogen excretion. Excreted nitrogen comes basically from excess amino acids, from microbial proteins, proteins undigested by the animals, and a part is endogenous (Penz Junior et al., 1999).

There was no interaction $(\mathrm{P}>0.05)$ between lysine and methionine+cystine levels for any of the performance characteristics evaluated up to 50 days of age (Table 3); likewise, the rise in methionine+cystine levels in the diets did not influence $(\mathrm{P}>0.05)$ the performance of rabbits up to 50 days of age.

Table 2 - Mean daily estimates ( $\mathrm{g}$ ) of nitrogen intake, nitrogen excreted in feces, nitrogen excreted in urine and retained nitrogen in NZW rabbits according to lysine and methionine+cystine (met+cys) levels, evaluated between 31 and 50 days of age

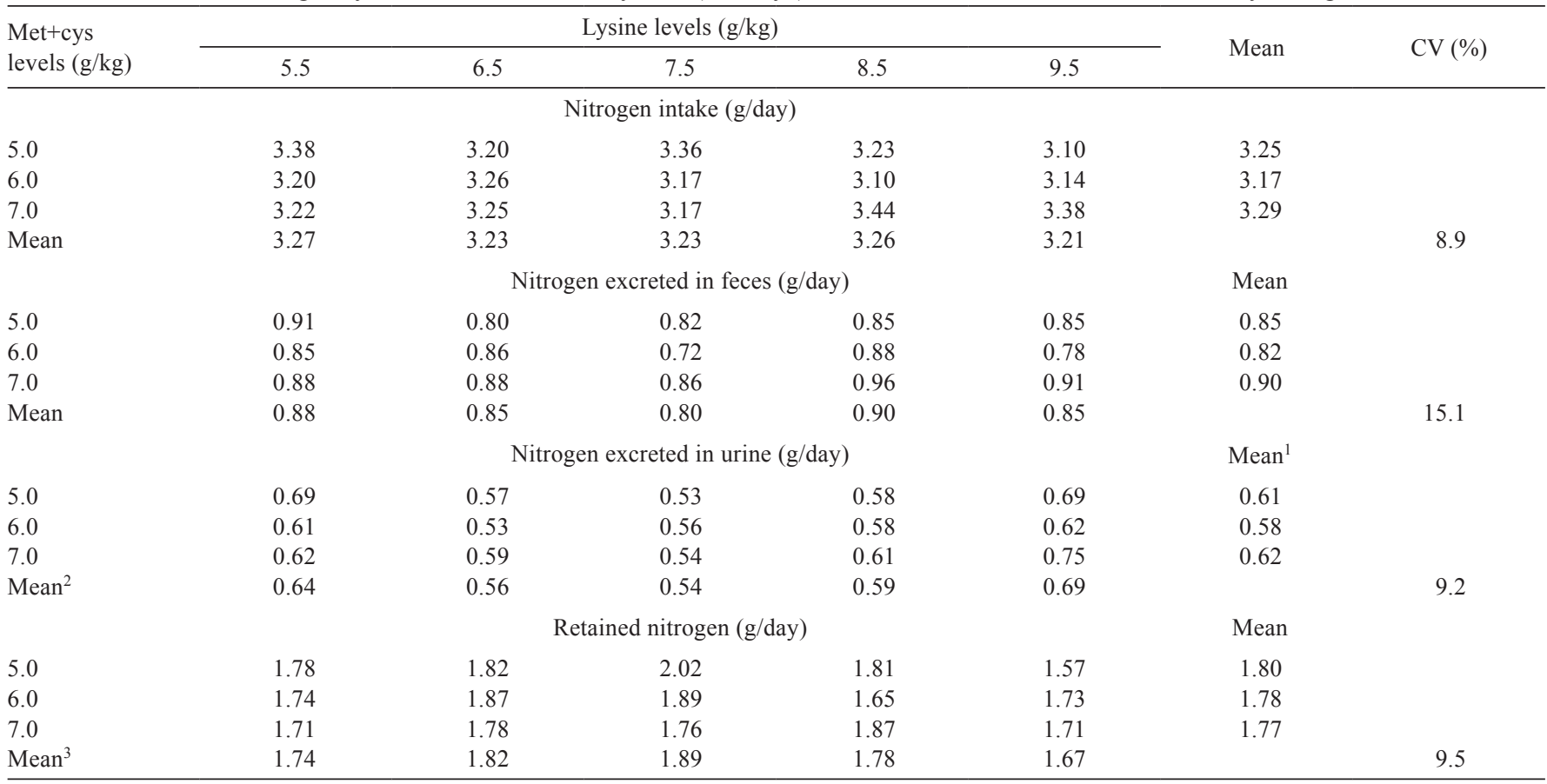

$\mathrm{CV}$ - coefficient of variation.

${ }^{1} \mathrm{Y}=12.3-0.0295 \mathrm{X}+0.025 \mathrm{X}^{2} ; \mathrm{R}^{2}=0.98(\mathrm{met}+\mathrm{cys}=5.9 \mathrm{~g} / \mathrm{kg})$

${ }^{2} \mathrm{Y}=13.255-0.027057 \mathrm{X}+0.01857 \mathrm{X}^{2} ; \mathrm{R}^{2}=0.99($ lysine $=7.28 \mathrm{~g} / \mathrm{kg})$

${ }^{3} \mathrm{Y}=-1.4675+0.0362 \mathrm{X}+0.025 \mathrm{X}^{2} ; \mathrm{R}^{2}=0.94($ lysine $=7.24 \mathrm{~g} / \mathrm{kg})$ 
Nevertheless, body weight at 50 days of age, daily weight gain and feed conversion showed quadratic effect $(\mathrm{P}<0.05)$ of lysine level, with the best results obtained with levels $7.5,7.38$ and $7.36 \mathrm{~g} / \mathrm{kg}$, respectively, calculated as a function of real levels $(5.5,6.5,7.5,8.5$ and $9.5 \mathrm{~g} / \mathrm{kg})$, using estimates.

The performance results reinforced those obtained for nitrogen balance (Table 2). Lysine inclusion levels have similar responses to lower $\mathrm{NU}(7.28 \mathrm{~g} / \mathrm{kg})$, maximum NR $(7.24 \mathrm{~g} / \mathrm{kg})$, higher DWG $(7.38 \mathrm{~g} / \mathrm{kg})$ and superior FC $(7.36 \mathrm{~g} / \mathrm{kg})$, suggesting that the improved amino acid profile may have favored tissue deposition by the rabbits.

Champe \& Harvey (1997) report that lysine is used specifically in body protein deposition. Therefore, the quadratic effect of lysine levels observed in this work is related to the improved amino acid profile of the diet, allowing greater absorption, retention and use of protein, when provided to animals according to their requirements, resulting in improved animal performance.

Similar results were found by Scapinello et al. (1995a), who, based on the improved feed conversion results, estimated that lysine requirements for rabbits between 35 and 70 days are $7.0 \mathrm{~g} / \mathrm{kg}$ in ration. However, those authors considered a single growth stage, between weaning and slaughter. Carregal (1998) estimated higher optimal lysine levels for growing rabbit diets, obtaining a higher daily weight gain, when the animals were fed $7.6 \mathrm{~g} / \mathrm{kg}$ of lysine.

The addition of a limiting nutrient in the diet, maintaining adequate levels of the other nutrients, promotes animal growth until its requirement is met. From then on, there is a range of growth stabilization and after, depending on the nutrient, weight loss may occur (Euclydes \& Rostagno, 2001).

Whenever diets feature excessively high levels of protein, antagonism can occur. These interrelations take place when diets with unbalanced amino acid ratios are provided, resulting in great loss of amino acids and concentrations of urea in the blood (Andriguetto, 2002).

There was no interaction $(\mathrm{P}>0.05)$ between the lysine and methionine+cystine levels for the evaluated carcass yield and characteristics of rabbits slaughtered at 50 days of age (Table 4)

The obtained results suggest that the lowest studied level $(5.5 \mathrm{~g} / \mathrm{kg})$ is sufficient to meet the performance requirements of the animals. These results are close to those found by Scapinello et al. (1995a), which demonstrated that for the phase between 35 and 90 days of age, the lowest level of lysine $(5.0 \mathrm{~g} / \mathrm{kg})$ in diets met the requirements of the animals.

For amino acid methionine+cystine, no isolated influence $(\mathrm{P}>0.05)$ of the levels in the diets was observed

Table 3 - Estimated means for body weight at 50 days and daily weight gain, daily feed intake and feed conversion of NZW rabbits according to lysine and methionine+cystine (Met+cys) levels, evaluated between 31 and 50 days of age

\begin{tabular}{|c|c|c|c|c|c|c|c|}
\hline \multirow{2}{*}{$\begin{array}{l}\text { Met+cys } \\
\text { levels }(\mathrm{g} / \mathrm{kg})\end{array}$} & \multicolumn{5}{|c|}{ Lysine levels (g/kg) } & \multirow{2}{*}{ Mean } & \multirow{2}{*}{ CV $(\%)$} \\
\hline & 5.5 & 6.5 & 7.5 & 8.5 & 9.5 & & \\
\hline \multicolumn{8}{|c|}{ Body weight at 50 days (g) } \\
\hline 5.0 & 1420 & 1460 & 1491 & 1439 & 1426 & 1447 & \\
\hline 6.0 & 1457 & 1370 & 1568 & 1533 & 1469 & 1479 & \\
\hline 7.0 & 1497 & 1544 & 1487 & 1437 & 1460 & 1485 & \\
\hline \multirow[t]{2}{*}{ Mean $^{1}$} & 1458 & 1458 & 1515 & 1470 & 1452 & & 8.1 \\
\hline & \multicolumn{5}{|c|}{ Daily weight gain (g) } & Mean & \\
\hline 5.0 & 35.5 & 35.8 & 36.2 & 34.9 & 32.3 & 35.0 & \\
\hline 6.0 & 35.7 & 31.7 & 39.6 & 39.1 & 34.2 & 36.1 & \\
\hline 7.0 & 32.5 & 39.6 & 36.1 & 34.8 & 33.8 & 35.4 & \\
\hline \multirow[t]{2}{*}{ Mean $^{2}$} & 34.6 & 35.7 & 37.3 & 36.3 & 33.4 & & 9.3 \\
\hline & \multicolumn{5}{|c|}{ Daily feed intake (g) } & Mean $^{1}$ & \\
\hline 5.0 & 103.9 & 99.8 & 96.3 & 105.1 & 100.0 & 101.0 & \\
\hline 6.0 & 101.4 & 95.0 & 95.2 & 101.8 & 99.8 & 98.6 & \\
\hline 7.0 & 97.2 & 103.7 & 99.3 & 92.4 & 98.6 & 98.2 & \\
\hline \multirow[t]{2}{*}{ Mean } & 100.8 & 99.5 & 96.9 & 100.1 & 99.3 & & 13.0 \\
\hline & & \multicolumn{3}{|c|}{ Feed conversion $(\mathrm{g} / \mathrm{g})$} & & Mean & \\
\hline 5.0 & 2.9 & 2.8 & 2.7 & 3.0 & 3.1 & 2.9 & \\
\hline 6.0 & 2.8 & 3.0 & 2.4 & 2.6 & 2.9 & 2.7 & \\
\hline 7.0 & 3.0 & 2.6 & 2.8 & 2.7 & 2.9 & 2.8 & \\
\hline Mean $^{3}$ & 2.9 & 2.8 & 2.6 & 2.8 & 3.0 & & 10.7 \\
\hline
\end{tabular}

$\mathrm{CV}$ - coefficient of variation.

${ }^{1} \mathrm{Y}=935.85+1.47857 \mathrm{X}-0.986 \mathrm{X}^{2} ; \mathrm{R}^{2}=0.52($ lysine $=7.5 \mathrm{~g} / \mathrm{kg})$.

${ }^{2} \mathrm{Y}=-4.265+0.111771 \mathrm{X}-0.07571 \mathrm{X}^{2} ; \mathrm{R}^{2}=0.91($ lysine $=7.38 \mathrm{~g} / \mathrm{kg})$.

${ }^{3} \mathrm{Y}=6.545-0.010514 \mathrm{X}+0.007143 \mathrm{X}^{2} ; \mathrm{R}^{2}=0.86($ lysine $=7.36 \mathrm{~g} / \mathrm{kg})$. 
on the carcass yield of rabbits slaughtered at 50 days of age, indicating that the lowest level of that amino acid used $(5.0 \mathrm{~g} / \mathrm{kg})$ meets the requirements of rabbits at that age.

These results agree with those found by De Blas \& Wiseman (1998), who indicated $5.0 \mathrm{~g} / \mathrm{kg}$ of methionine+cystine in diets for growing rabbits.

No differences were observed $(\mathrm{P}>0.05)$ among treatments for meat:bone ratio, which suggests that muscle protein deposition remained constant in all proposed treatments. Likewise, no differences were observed $(\mathrm{P}>0.05)$ between evaluated treatments in the cost of the diet.

Comparing the results and estimation of the polynomial equations from the nitrogen balance experiment to the performance assay, it was observed that the optimal levels of lysine $(7.28$ and $7.5 \mathrm{~g} / \mathrm{kg})$ and methionine+cystine $(5.9$ and $5.0 \mathrm{~g} / \mathrm{kg}$ ), respectively, estimated for both variables, are quite close, suggesting that up to that level animals take advantage of the amino acids present in the diet; beyond that level, rabbits do not show increased performance, with loss of the excess ingested nitrogen, possibly even resulting in decreased animal performance.

This decline can be explained by the reduced retention of nitrogen by rabbits, thus increasing the excretion of nitrogen compounds in the environment, and lower use of amino acids provided in the diet.

With regard to amino acid requirements, the international literature shows $7.5 \mathrm{~g} / \mathrm{kg}$ for lysine, $5.4 \mathrm{~g} / \mathrm{kg}$ for methionine + cystine, and $6.4 \mathrm{~g} / \mathrm{kg}$ for threonine values. Domestic experiments propose values between 7.0 and $7.6 \mathrm{~g} / \mathrm{kg}$ of lysine in the diet, and 4.6 to $6.0 \mathrm{~g} / \mathrm{kg}$ of methionine + cystine

Table 4 - Estimated means of carcass yield, hindquarters, sirloin, forequarter, thoracervical region, meat:bone ratio and ration costs according to lysine and methionine+cystine (Met+cys) levels for NZW rabbits at 50 days of age

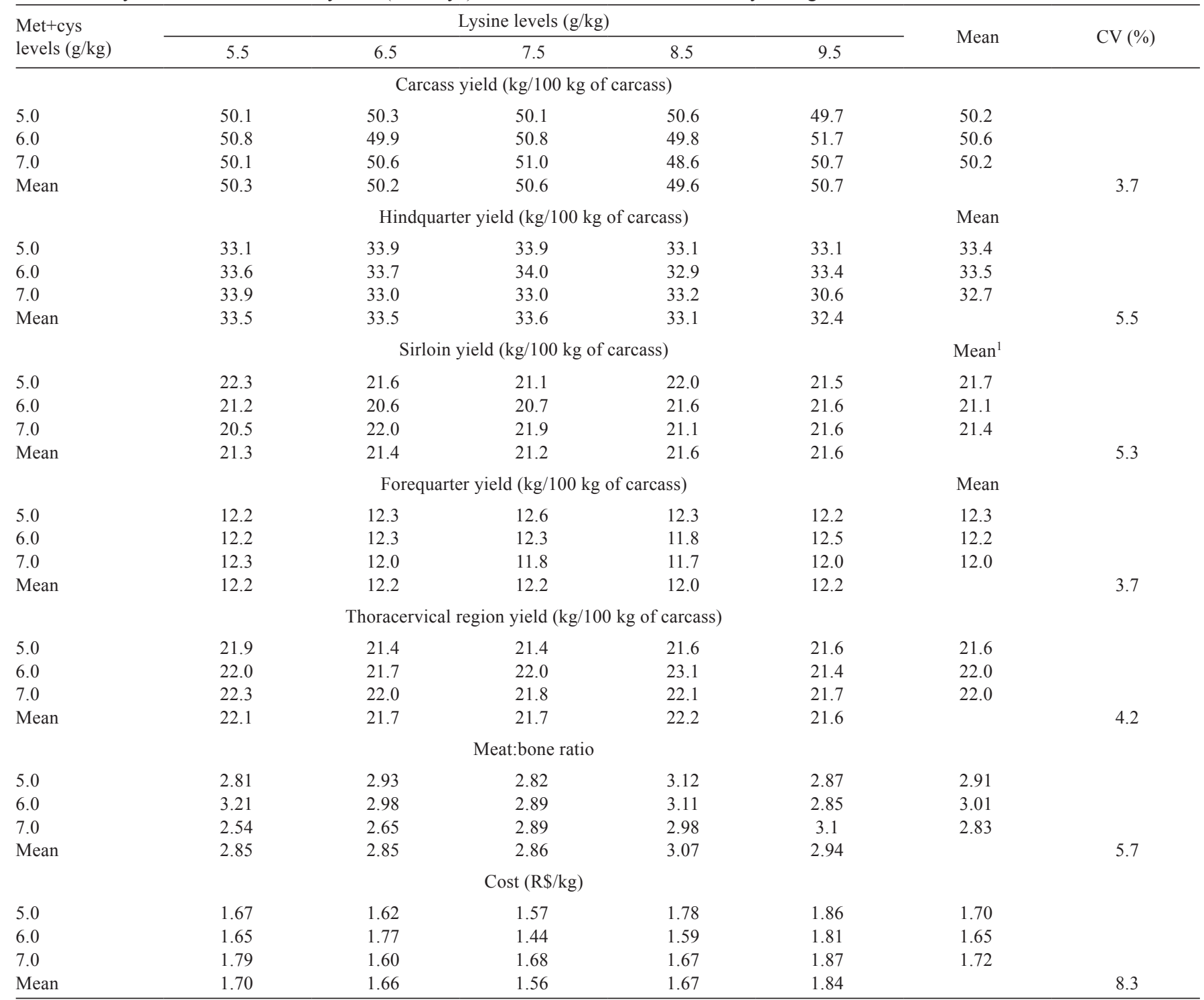

$\mathrm{CV}$ - coefficient of variation 
(Machado et al., 2011). Studies by De Blas (2010) show results for requirements of lysine and methionine+cystine of 7.3 and $5.2 \mathrm{~g} / \mathrm{kg}$, respectively.

\section{Conclusions}

For rabbits between weaning and 50 days of age, lysine and methionine+cystine are recommended at 7.4 and $5.0 \mathrm{~g} / \mathrm{kg}$ in the diets, respectively.

\section{References}

ADAMSON, I.; FISHER, H. The amino acid requirements of the growing rabbit: Qualitative needs. Nutrition Reports International, v.4, p.59-64, 1971.

ADAMSON, I.; FISHER, H. Amino acid requirement of the growing rabbit: An estimate of quantitative needs. Journal of Nutrition, v.103, p.1306-1310, 1973.

ANDRIGUETTO, J.M. Nutrição animal. São Paulo: Nobel, 2002. 395p.

BARBOSA, M.J.B.; JUNQUEIRA, O.M.; ANDREOTTI, M.O. et al. Exigência de lisina e metionina+cistina digestíveis para frangos de corte na fase final. Acta Scientiarum, v.24, n.4, p.1001-1006, 2002.

BELLAVER, C.; FIALHO, E.T.; PROTAS, J.F.S. et al. Radícula de malte na alimentação de suínos em crescimento e terminação. Pesquisa Agropecuária Brasileira, v.20, n.8, p.969-74, 1985.

CARREGAL, R.D. Níveis de lisina em dietas de coelhos em crescimento, In: REUNIÃO ANUAL DA SOCIEDADE BRASILEIRA DE ZOOTECNIA, 35., 1998, Botucatu. Anais... Botucatu: Sociedade Brasileira de Zootecnia, 1998. p.413-415.

CHAMPE, P.; HARVEY, R. Bioquímica ilustrada. 2.ed. Porto Alegre: Editora Artes Médicas, 1997. 446p.

CHEEKE, P.R. Arginine, lysine and methionine needs of the growing rabbits. Nutrition Reports International, v.3, p.123-128, 1971.

COLIN, M. Effets sur la croissance du lapin de la supplémentation en 1-lysine et en dlméthionine de régimes végétaux simplifiés. Animal Research, v.24, p.465-474, 1975.

DAVIDSON, J.; SPREADBURY, D. Nutrition of the New Zealand White rabbit. The Proceedings of the Nutrition Society, n.34, p.75-83, 1975.

DE BLAS, C.; WISEMAN, J. The nutrition of the rabbit. Cambridge: CABI Publishing, 1998. 344p.

DE BLAS, C.; WISEMAN, J. The nutrition of the rabbit. 2.ed. Cambridge: CAB International, 2010. p.222-232.

EUCLYDES, R.F.; ROSTAGNO, H.S. Estimativa dos níveis nutricionais via experimentos de desempenho. In: WORKSHOP LATINO-AMERICANO AJINOMOTO BIOLATINA, 1., 2001, Foz do Iguaçu. Anais... Foz do Iguaçu: Ajinomoto Biolatina, 2001. p.77-88.

EUROPEAN GROUP ON RABBIT NUTRITION - EGRAN. Harmonization in rabbit nutrition research: Recommendations to analise some basic chemical components of feeds and faeces. In: WORKSHOP OF EGRAM, 1999, Madrid. Proceedings... Madrid: European Group on Rabbit Nutrition, 1999. p.10.

GAMAN, E.; FISHER, H. The essentiality of arginine, lisyne and methionine for growing rabbits. Nutrition Reports International, v.1, p.57-64, 1970 .
GOMES, A.V.C.; CRESPI, M.P.A.L.; COLL, J.F.C. et al. In: REUNIÃO ANUAL DA SOCIEDADE BRASILEIRA DE ZOOTECNIA, 29., 1992, Lavras. Anais... Lavras: Sociedade Brasileira de Zootecnia, 1992. p.522.

GOMES, A.V.C.; CRESPI, M.P.A.L.; COLL, J.F.C. et al. Desempenho produtivo de coelhos da raça Nova Zelândia Branca submetidos a diferentes níveis de metionina + cistina. In: REUNIÃO ANUAL DA SOCIEDADE BRASILEIRA DE ZOOTECNIA, 42., 2005, Goiânia. Anais... Goiânia: Sociedade Brasileira de Zootecnia/ Gmosis, [2005]. (CD-ROM).

LEBAS, F.; COUSIN, M.C.; SARDI, G. Effet de la teneur en protéines de rations a base de soja ou de sésame sur la croissance du lapin. Animal Research, v.22, p.83-92, 1973.

LEBAS F. Reflections on rabbit nutrition with a special emphasis on feed ingredients utilization. In: WORLD RABBIT CONGRESS, 8., 2004, Puebla, Mexico. Proceedings... Puebla, Mexico, 2004. p.686-736

MACHADO, L.C.; FERREIRA, W.M.; SCAPINELLO, C. et al. Manual de formulação de ração e suplementos para coelhos. Bambuí: Ed. do Autor, 2011. 24p.

MCWARD, G.W.; NICHOLSON, L.B.; POULTON, B.R. Arginine requirement of the young rabbit. Journal of Nutrition, v.92, p.118-120, 1967.

NATIONAL RESEARCH COUNCIL - NRC. Nutrient requirements of rabbits. Washington, D.C.: National Academic of Science, 1977. 30p.

OJEWOLA, G.S.; ABASIEKONG, S.F.; UKO, M.U. et al. Reproductive performance of rabbits fed graded levels of methionine in a tropical environment. Journal of Animal and Veterinary Advances, v.5, n.2, p.118-121, 2006.

PENZ JUNIOR, A.M.; MEINERZ, C.E.; MAGRO, N. Efeito da nutrição na quantidade e na qualidade dos dejetos de suínos. In: REUNIÃO ANUAL DA SOCIEDADE BRASILEIRA DE ZOOTECNIA, 36., 1999, Porto Alegre. Anais... Porto Alegre: UFRGS, 1999. p.281-294.

PINTO, H.F.; CARREGAL, R.D. Efeito da adição de DL-Metionina na ração de coelhos Selecta, em fase de crescimento. Revista da Sociedade Brasileira de Zootecnia, v.23, n.5, p.813-822, 1994.

RAO, D.R.; CHEN, C.P.; SUNKI, G.R. et al. Effect of weaning and slaughter ages on rabbit meat production. II. Carcass quality and composition. Journal of Animal Science, v.46, p.578-583, 1978.

RUTZ, F. Metabolismo intermediário. In: MACARI, M.; FURLAN, R.L.; GONZÁLES, E. (Eds.) Fisiologia aviária aplicada a frangos de corte. 2.ed. Jaboticabal: FUNEP/UNESP, 2002. 375p.

SAKOMURA, N.K.; ROSTAGNO, H.S. Métodos de pesquisa em nutrição de monogástricos. Jaboticabal: Funep, 2007. 283p.

SCAPINELLO, C.; TAFURI, M.L.; ROSTAGNO, H.S. et al. Exigência de lisina para coelhos da raça Nova Zelândia Branco em crescimento. Revista da Sociedade Brasileira de Zootecnia, v.24, n.6, p.972-980, 1995a.

SCAPINELLO, C.; TAFURI, M.L.; ROSTAGNO, H.S. et al. Exigência de metionina+cistina para coelhos da raça Nova Zelândia Branco em crescimento. Revista da Sociedade Brasileira de Zootecnia, v.24, n.6, p.981-991, 1995b.

SILVA, D.J.; QUEIROZ, A.C. Análise de alimentos (métodos químicos e biológicos). 3.ed. Viçosa, MG: UFV, 2002. 235p.

SPREADBURY, D. A study of the protein and amino acid requirements of the growing New Zealand White rabbit with emphasis on lysine and the sulphur containing amino acids. The British Journal of Nutrition, v.39, p.601-603, 1978. 